\title{
AGENCY, LEARNING AND IDENTITY IN WOMEN'S LIFE TRAJECTORIES
}

\author{
CAPACITÉ D'AGIR ET D'APPRENDRE A 50 ANS : TRAJECTOIRES DE VIE DES \\ FEMMES
}

\author{
Karen Evans ${ }^{1}$, Chiara Biasin ${ }^{2}$ \\ ${ }^{1}$ UCL Institute of Education, University of London, United Kingdom; ${ }^{2}$ University of Padua, Italy
}

\begin{abstract}
Drawn from the longitudinal panel research of the National Child Development Study (NCDS), a sample of 110 women aged fifty years old from England, Scotland and Wales were interviewed as part of the Social Participation and Identity sub-project. They were invited to tell their life stories, to give a self-definition of identity and to describe the turning points in their lives. They were also invited to choose a visual representation of their life trajectories, either selecting from 8 given figures with the possibility of drawing their own version. We analyse the resulting life course diagrams which were drawn, focusing on self representations in which agency and learning are reflected in the associated personal narratives on turning points. Emphasis is given to the links between agency and learning and identity development within the perspective of the life trajectories.
\end{abstract}

El National Child Development Study (NCDS 6691) es un estudio longitudinal, sobre las personas nacidas en el Reino Unido en una semana específica de 1958. Esta investigación tuvo como objetivo analizar los factores que caracterizan el desarrollo humano durante toda la vida. En particular, el estudio Social Participation and Identity es una sub-muestra de NCDS sobre estas personas, las cuales fueron entrevistadas a los 50 años para analizar en profundidad sus historias de vida. Para ello, se llevaron a cabo 222 entrevistas compuestas por 31 ítems, en Inglaterra, Escocia y Gales. A partir de esta base de datos, se seleccionó una muestra de 110 mujeres de cincuenta años, y se les realizó una entrevista centrada en cinco preguntas específicas. Se les invitó a hablar de su historia de vida, dar una definición de sí mismas y describir los acontecimientos clave de su existencia. Concretamente, una de las preguntas específicas invitaba a estas mujeres a buscar una representación visual de su propio recorrido vital, a través de la elección de uno de los ocho esquemas datos que se les proporcionaban. Sin embargo, al mismo tiempo se les ofreció la posibilidad de dibujar su propia trayectoria personal fuera de los modelos propuestos, mediante una auto-representación gráfica elaborada por ellas mismas. Este artículo analiza los esquemas de recorrido vital de las 31 mujeres que decidieron representar su historia de vida sin utilizar ninguno de los modelos ofrecidos, debido a que la elección de diseñar su propia trayectoria vital fue considerada como una forma de auto-definición de la identidad personal que implica conciencia, y responsabilidad. En particular, el análisis se ha centrado en las 16 auto-representaciones gráficas de la identidad en las que la agency y la capacidad de auto-aprendizaje están presentes. Se analizó la capacidad de auto-dirección en el aprendizaje y la capacidad de controlar las trayectorias vitals.

Le National Child Development Study (NCDS 6691) est une recherche longitudinale sur les personnes nées au Royaume-Uni dans une spécifique semaine du 1958. Cette recherche a pour but d'étudier les facteurs qui caractérisent le développement humain tout au long de la vie. L'étude Social Participation and Identity est un sous-échantillon du NCDS concernant ces personnes, consultées à l'âge de 50 ans; il analyse en profondeur les membres d'une cohorte d'âge à partir de leur histories de vie. Deux cent et vingt-deux interviews, composés de 31 questions, ont été réalisés en Angleterre, Écosse et Galles. A partir de cette base de données, on a sélectionné un échantillon de 110 femmes interrogées à 50 ans, en focalisant l'attention sur cinq spécifiques questions de l'interview. Les femmes sont invitées à parler de leur histoire de vie, à donner une définition de soi, en racontant les événements-clé de leur existence. L'une de ces questions sollicitait à choisir une représentation visuelle du parcours de vie entre 8 schémas 
qui symbolisaient le mieux leur vie, avec la possibilité d'esquisser par eux-mêmes la trajectoire de vie. On va explorer les diagrammes du parcours de vie tracés par $31 \mathrm{femmes,} \mathrm{sans} \mathrm{l'aide} \mathrm{des} \mathrm{huit} \mathrm{modèles}$ offerts. Le choix de réaliser sa propre trajectoire est donc étudié comme une forme d'expression de soi, voir d'autodéfinition de l'identité personnelle qui sollicite des formes d'agentivité et de responsabilité. En particulier, on focalise l'attention sur 16 autoreprésentations de l'identité dans lesquelles l'agentivité et la capacité d'apprendre sont différemment affirmées dans les histoires de vie racontées dans les entretiens.

Key words

Life course; women aged 50; life trajectories; agency; identity

\section{Introduction}

This paper discusses the ways in which a group of women aged 50, from contrasting cultural contexts, narrate and portray turning points in their life course, with particular reference to the relationships between identity, agency and experiences of learning, including opportunities to learn through work and life experiences. Their narratives and representations are interpreted as reflections of identity (Kirpal 2011) and also of the complex sets of motivations, beliefs and dispositions towards learning and their own capabilities for taking action to change their situations. To explore their representations of turning points in their lives, we draw on theories of life course (Heinz and Krüger, 2001; Ecclestone et al., 2009; Biasin, 2012) and, in particular, approaches relevant to the study of women aged fifty, assumed as an age of specific transitions in the life course (Sugarman, 1986; Stewart and al., 2001). Personal agency is understood as a bounded process that is exercised through environments, drawing on the conceptualisations of human agency developed by Evans (2002; 2007; 2016) and Biesta et al. (2011). The perspective of biographical learning (Alheit and Dausien, 2002; Tedder and Biesta, 2007; Hallqvist et al., 2012) reveals aspects of the narrative-in-action which allow adults to negotiate and to make claims about different life events and specific experiences of success or failure and opportunities or setbacks at any stage. Furthermore, these narratives can reveal how and what these women have learnt from their lives and from self-insight, creating or limiting learning potential for the future (Hallqvist 2012; Carré 2013).

\section{Methodology}

The NCDS is a UK based panel study investigating the biographies of a sample of 17.000 people born in one specific week in 1958, whose lives have been tracked longitudinally up to the present day. A sub-sample of the NCDS data consists of a set of 220 semi-standard 
interviews conducted with equal numbers of women and men at the age of 50. They were conducted in England, Scotland and Wales and covered five main topics: neighbourhood and belonging, cultural participation, friendship and family, life stories and identities. Respondents were also asked to choose, from eight life-course diagrams, the one that best matched their life trajectory or to draw their own representation. Our analysis focuses on two sections of these interviews in which respondents describe the most important influences and turning points in their life-story and how they define their selves. From the sub-sample of 110 women, we selected 16 out of 31 cases in which they chose to draw their own life diagram because they used the sketching process to show ups, downs and lateral movements, paying particular attention to changes in direction of their life-trajectory. They all provide explications of their diagrams that could not have been draw from the eight standard life course diagrams.

In this paper we focus our analysis on these 16 life narratives and their graphic representations with the aim of understanding the implicit meanings (tacit and naive theory-in-use) of the ideas of turning points and movements 'up and down' expressed therein. We also aim to show the relationship between agency, learning and identity embedded in narratives and its significance in influencing the way the women coped with life turning points.

Research questions are: How do women represent their life trajectories? How can their narratives and drawings be understood in terms of what they have learnt from their lives or from their inner sense of themselves? How do women's accounts of how they have coped with life's turning points reflect the relationship between agency, identity and learning?

The methodological approach is qualitative (Mattingly, 2007). The interviews are studied with the content analysis based on the transcriptions using Nvivo, including thematic, the linguistic and the narrative analysis. The validity of the results is constantly verified by a continuous process of discussion and by a compared analysis conducted by the authors both separately and together. The interviews are analysed, first by coding representations of agency, learning and identity embedded in the narratives and then according to the conceptual distinctions highlighted by the narrative learning approach, where emphasis is put on impact of learning in storyteller's life and on the narrator's identity and agency (Biesta et al., 2008, 11).

\section{Findings}

The analysis of the stories identifies a number of expressions of agency and learning embedded in the accounts. To Table 1 summarizes the data. Using different combinations of agency (low agency = A-; high agency $=\mathrm{A}+$ ) and learning (low learning $=$ L-; high learning $=\mathrm{L}+$ ) four profiles of identity emerge from the weak or strong presence of agency or learning in the 
women's lives. These configurations are not considered as a moral or judgmental labelling but are used to indicate the recurrent pattern of responses in the interviews.

Tab.1 - Profile combinations

\begin{tabular}{|ccc|}
\hline PROFILE & $\begin{array}{c}\text { PROFILE } \\
\text { ACRONYM }\end{array}$ & COMBINATION \\
\hline Contained & $\mathrm{C}$ & $-\mathrm{L}-\mathrm{A}$ \\
\hline Reactive & $\mathrm{R}$ & $+\mathrm{L}-\mathrm{A}$ \\
\hline Testing & $\mathrm{T}$ & $-\mathrm{L}+\mathrm{A}$ \\
\hline Conscious and Reflective & $\mathrm{CR}$ & $+\mathrm{L}+\mathrm{A}$ \\
\hline
\end{tabular}

In the Contained profile of responses (Acronym C), women use few expressions of agency or learning; they see themselves as having few options or as being restricted in their life choices, as indicated in these examples: "I think it's just because I've not got any interests or things like that, so, aye, I would say sometimes I am quite boring. The Reactive profile (acronym R) emerges from the responses characterised by expressions of learning, but with little occurrence of statements indicating agency or personal beliefs in ability to change aspects of their situations through personal action. Typical expressions include: "I've never been an ambitious person to become, you know, a business woman or anything like that but whatever I do, I like to do well and properly, so I wouldn't take on anything I didn't think I was either capable of doing or capable of learning how to do properly". In the Testing profile (acronym T), the subjects describe examples of action-taking in their lives, but they talk about these without any reference to learning or self-insight. For example: "I'm like 'well, try anything'. And this I guess is--, I don't know if that represents now, it's just that sense of I know there's a period of stability and that lovely word you said, renewal, but I know it will go up again (into crisis) and I think somehow that's the bit that I want to change, my response to it'. Conscious and reflective expressions of identity (acronym CR) are frequent in the personal accounts where the women talk explicitly about self insight gained from their life trajectories: "I stuck it for four years, it fitted in with the boys, and my husband and I split up and I thought, oh I--, I need to--, there was like no--, there was no potential there then to earning my--, enough money, you know, and I thought, I've got to--, I've got to move on now and I went back to the bank, heaven forbid, that had changed so much, you know, you had to be a salesperson".

The analysis of these 16 stories aims to identify how and what these women have learned from their lives or from their sense of self as they have experienced the ups, downs and lateral 
movements visualised in their drawings. It was only in the profile CR (Conscious and Reflective) that we could observe them expressing conscious and reflective capabilities, related to concepts of self-learning as a continuous process of self-development (Carré, 2012, 2013). All the 16 narratives were analysed with the focus on the process of narrative construction, not on the narrative as "product". We assume that the process of narrative constructing and reconstructing is a form of "learning in action" that grows from internal agendas and from the self project as a search for personal meaning in the life course. Using the conceptual distinctions based on Biesta et al. (2008), we highlight, in a deeper analysis, the differences and specificities in the 16 narratives, according a selection of descriptive categories: the plot, the life course account, the key-persons and the key-events, the core identity, the narrative character, the self position in narrative, the scripts, the type of learning, the reflective capabilities and the self definition.

These illustrations are provided to help to explain this analysis, they provide a description of one case of each type of profile. The first shows the expressions associated with the Conscious and Reflective profile $(+\mathrm{L}+\mathrm{A})$, in case number $27^{1}$.

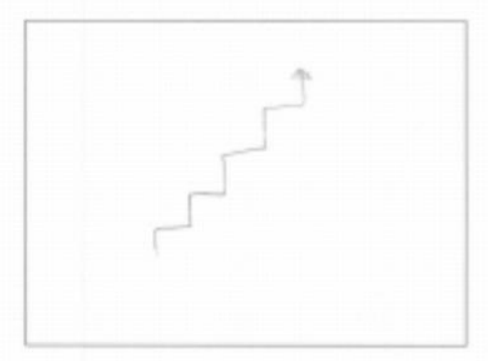

After working in a range of occupations (bank, optician), her son's graduation is considered as a turning point that led her to advance her own learning (by enrolling in a $\mathrm{PhD}$ ) and later-life identity development. The sequence is a chronological series of passages: infancy, school, (no adolescence), job, partner, job changes, son, degree and PhD. No specific or traumaticlchallenges events are described; the "insight" arising from the son's graduation is tied to the decision to advance her own learning. No justification is given for her life choices. Telling the story seems to help her to find the main theme (fil rouge) of her life and to identify potential for self-development. The story has the function of reminding her of who she is and whence she is coming towards her actual self. Many reflections on her identity or events seem to be important not for the task (the interview) but for her personal empowerment. Reflection for her is a form of awareness about herself and the way she spontaneously takes up opportunities as they arise (for example, job changes). The gap between the self-as-narrated and the self-as-narrator narrows as the story progresses. In the beginning, the narrator presents the self as located in earlier times (a distant self "I can remember") recounting experiences perceived as remote and hidden in the past. The self unfolds with and

\footnotetext{
${ }^{1}$ This and the other numbers are referred to the specific case, chosen for our paper, from the 220 cases of the sample.
} 
throughout the narration drawing closer to the present self. She learns from her story about herself because she becomes more and more conscious of her (learner) identity, centred on her passion for learning science. "Biologist" is the dimension of identity that she wants to be socially recognized. The identity is embedded in the profession and takes her beyond the influence of the family. She recognizes a tendency to low self-esteem: "sometimes I can't think of myself as being at that level" and she defines herself "quite happy".

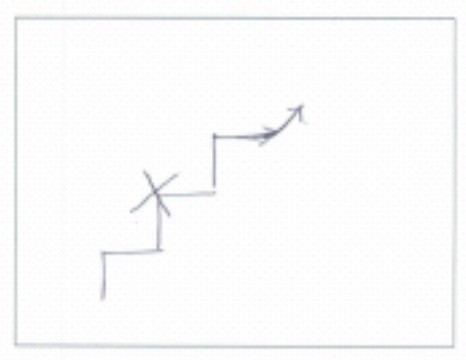

This visualisation can be contrasted with case $\mathrm{n} .41$ : a narrative that we interpret as having a Reactive Profile $(+\mathrm{L}-\mathrm{A})$ in which we found expressions of learning, but a less pronounced level of agency. The narrative is organised around the cross-roads in her life and her decision to organise her life around her children. The identity narrative is explicitly linked to the influence first of the father and then the husband. She explains that the main influence on her changed, when she married, from her husband to her father. The role of males (father, husband, brother) in her life characterized her identity as "dependent" in relation to these figures. The narrative is assembled around the crossroads in her diagram, which could be interpreted as self-justification about her major life choice: to have children instead of academic qualifications and career. Nevertheless, she needs to be protected, assured, persuaded and supported in her choices. She justifies dependence on partner's views "because of the work he does".

Reactions to events and decisions such as changes in job are not autonomous but reliant on support, affirmation and supervision revealing other-oriented identity with little selfdirectedness. She speaks more and more to her self because she is the centre of the story. All the events are collected around her as the focal point; but she does not talk about learning through self-insight or reflection on life experiences. Changes of job are considered as new learning; actions tend to be "reactive" and highly dependent on dominant others, from whom she takes her steer, restricting self-determination in learning but revealing self awareness and potential for learning from her life.

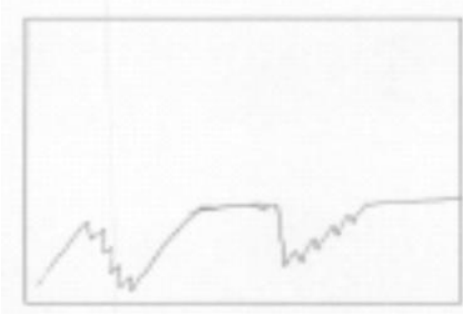

These two patterns of stories can be compared with a narrative characterised by few expressions of both agency and learning, which feature in the Contained profile (-L -A). This woman (case n.188) describes her life as series of jobs and births of children until she returns to work in a bank (her original job) for the next 24 years. This interview reveals some difficulties the respondent had in making 
her lifeline; she needed prompting by the interviewer to cover some periods and events in her life. There are few points of reference. The main ones that the interviewer elicits are the fact that she lived abroad during her teens, her mother's addiction and the tensions in her relationships with her brother. There are very few details about her husband, or daughters and no references to learning beyond schooling. There is little sense that she feels she has learned or can learn from her life. Her biography is narrated as a linear sequence of events: left school, job, married, pregnant, left job, first daughter, second daughter, back to the (same) job. She seems to have some difficulties in telling her story, which may reflect reticence or shyness (“Hmmm, what else have I done?"). She only replies to questions and does not reflect on her story: she analyses one central event at length involving the role she and her brother's played in a family conflict over an inheritance. There are few expressions of identity: she seems unable to communicate about herself in a positive way or to describe who she is:

"How do I define myself? I don't know. That's hard, how do you define yourself? Can you give me examples that I would--? Oh right, okay. I can't think, honestly I can't. [pause] I can't say I'm a happy person at the moment. [...] I've not got any interests or things like that, so, aye, I would say sometimes I am quite boring. I bore myself. I bore myself 'cause I don't do anything, but then I can be happy too. I just need a wee shove at the moment, I think that's what it is".
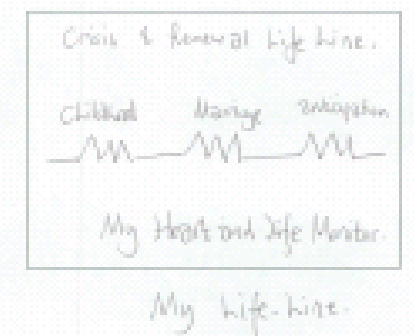

In Testing profile $(-\mathrm{L}+\mathrm{A})$, illustrated by case n.58, the woman's story has no sequential order because it is focused on the traumatic event of abuse when she was a child. She presents her life in a few descriptive lines: mum, school, husband, degree, qualification, job. The focus of the story is

the abuse not analysed rationally but expressed through emotion and feelings. Life is reconstructed around this event; she portrays it like an electrocardiograph, characterised by periods of stability interspersed with crises as she goes from one crisis event to the next e.g. debt upheavals in personal relationships etc. The primary function is the search for meaning and for peace (or inner justification). She learns from her life, its challenges and her difficulties rather than from her academic studies; she tries to do better, to find new possibilities that will change her story. Her narrative has within it conscious with reflective, analytic elements but she is always inside the original abuse event and cannot disconnect from it: for that reason, her reflections are a self-discourse in search of sense-making. The many facets of this search are separate not unified in a core; she tries to look at many possibilities but any learning that can move her life forward seems limited by the embedded self-discourse. In going from crisis to crisis, there is learning potential but it does not seem to take her forward. She dreams of making 
a new life far away from her present situation. There is as yet unfulfilled potential for self development which she herself identifies:

"I'm like 'well, try anything'. And this I guess is--, I don't know if that represents now, it's just that sense of I know there's a period of stability and that lovely word you said, renewal, but I know it will go up again (into crisis) and I think somehow that's the bit that I want to change, my response to it...".

Taken together, these cases illustrate how the profiles are derived from the analysis of narrative accounts. Of course, in practice there are some elements of reactivity and testing in reflective profiles and some glimpses of reflective learning in reactive cases. The classification is simply attempting to capture dominant patterns in responses and the researchers' interpretations of these. The analysis reveals the potential for learning that is embedded in life courses and, in particular, in the self-reflection that is contained in the identity narratives.

\section{Discussion and Conclusion}

Initial exploration of the full set of personal accounts of adult learning shows how these women portray specific experiences as 'activating events' that have the potential to not only trigger new learning orientations (values, attitudes towards learning) but may also change horizons. These changes can stimulate and foster greater confidence and willingness on the part of women to develop themselves in new ways. The reverse can also be true: individuals can become trapped by events and locked into their own stories. However, the impact of these shifting orientations on life trajectories, and the degree to which such changes are sustained over time, depend on cultural and systemic factors. In some cases, 'activating events' are described that have triggered new work attitudes and motivations to learn; sometimes pivotal points have been reached in and through significant relationships that have nudged some women towards broadening their horizons and galvanising their willingness to take on more challenging roles. In others, recurrent patterns of crisis and the search for stability characterise the ups and downs and turning points of the life course, in culturally-specific ways. In examining expressions of agency, learning and identity development in these women's life history narratives and self-representations, we have, so far, identified four recurrent profiles: Contained; Reactive; Testing; Conscious-Reflective. Forms of self-learning, in a broader and extended 'life course' definition, can also be recognised in the extent of each woman's ability to analyse her life and to push it forward a little. These self-learning capabilities appear most pronounced in cases that are characterised by conscious-reflective expressions of identity development. 
Carré et al. (2010) proposes an agenda for self learning which is life-wide, encompassing all domains of personal life, and life-deep, extending to the spiritual dimensions of life. What light can these women's narratives shed on self-learning processes in this extended sense? The questioning that has prompted these narratives does not ask the women to reformulate their experiences to explain them as 'learning projects'. The narrative accounts are elicited from answers given by NCDS research participants when they were asked to reflect on their life experiences and in particular on their own representations of their life course and on turning points in their lives. The accounts reveal identity development through agency and learning. The retrospective accounts show how the women's expressions of agency in a life course perspective can be understood as temporal (Emirbayer and Mische, 1998), reflecting how the habits and routines of the past and people's beliefs in what is possible for them in the future are brought together in decisions and action-taking in the contingencies of the present moment. This temporally embedded agency can be individual or collective and is not structurally determined, in the senses proposed by Bourdieu (1993), since horizons and imagined futures can be reflectively reformulated and re-imagined through a process of self-learning. Where this is the essence of narrative accounts of 'turning points', the identity development that takes place through agency and learning is not that of the self-propelled autonomous individual but, rather, relational and consciously reflective. Action and further learning potential are generated through the process of becoming consciously and reflectively engaged in self-development.

But the narratives also reveal aspects of the conditions and relationships through which these women came to express contained, reactive and testing identity profiles. These representations of the environments and relationships are also very significant in the process of evaluating the pre-conditions for self-learning. Such insights are often missing in assumptions that are made about self - determination and readiness for learning in adult life.

Our analysis of these narratives thus connects identity development with temporal understandings of agency and self-learning through the life course, and allows us to identify how self-representations reflect variations in ways of learning to cope with and move on from conditions and relationships that reflexively shape lives.

\section{Acknowledgements}

Work on this manuscript was supported by the UK Economic and Social Research Council (ESRC: RES-594-280001). Data from the National Cohort Development Studies were supplied by the ESRC Data Archive, UK Data 6991. Those who carried out the original collection of the data bear no responsibility for its further analysis and interpretation. We acknowledge the support of the LLAKES Centre, an ESRC funded Research Centre, grant reference ES/J019135/1, in writing this paper, which is a common and shared work based on equal contributions; however it is possible to attribute to K.Evans the typology analysis, discussion and conclusions and to C.Biasin the methodology and presentation of the 4 selected cases. 


\section{References}

Alheit, P., Dausien, B. (2002). The double face of lifelong learning. Two analytical perspective on a silent revolution. Studies in Education of Adults, 34, 1, 3-22.

Biasin, C., (2012). Le transizioni. Modelli e approcci per l'educazione degli adulti. Lecce: Pensa Multimedia.

Biesta, G.J.J., Goodson, I.F., Tedder, M. and Adair, N. (2008). Learning from life: The role of narrative. Learning lives summative working paper 2. Stirling: University of Stirling/The Learning Lives Project (http://www.learninglives.org; accessed at 21/03/2016).

Biesta, G., Field, J., Hodkinson, P., Macleod, F., Goodson, I. (2011). Improving Learning through the Life Course. London: Routledge.

Bourdieu, P. (1993). Sociology in Question. London: Sage.

Carré Ph., Poisson D., Moisan A. (2010). L'autoformation. Perspectives de recherche. Paris: PUF.

Carré Ph. (2012). The Double Dimension of Self-Directed Learning: Learners Experiment with Freedom. International Journal of Self-Directed Learning, IX, 2, 1-10.

Carré Ph. (2013) Heuristics of Adult Learning. In R.Hiemstra and Carre, P. A Feast of Learning: International Perspectives on Adult Learning and Change. Charlotte USA: Information Age Publishers.

Ecclestone, K., Biesta, G. and Hughes, M. (eds) (2009). Lost in Transition? Change and Becoming through the Life Course. London: Routledge Falmer.

Emibayer, M. and Mische, A. (1998). What is agency? American Journal of Sociology, 103, 4, 962-1023.

Evans, K (2002). Taking Control: Agency in Young Adult Transitions in England and Germany. Journal of Youth Studies, 5, 245-269.

Evans, K. (2007). Concepts of bounded agency in education, work, and the personal lives of young adults. International Journal of Psychology, 42, 2, 85-93.

Evans, K. (in press). Bounded Agency. Education Permanente. Hors-series.

Hallqvist, A., Ellström, P-E and Hydén, L-C. (2012). The many faces of biographical learning. Studies in the Education of Adults, 44, 1, 70-84.

Hallqvist, A. (2012). Work Transitions as Biographical Learning. Exploring the Dynamics of Job Loss. Doctoral Thesis Linköping University (http://www.divaportal.org/smash/record.jsf?pid=diva2\%3A515474\&dswid=-8301; accessed at 21/03/2016).

Heinz, W.R. and Krüger, H. (2001) Life Course: Innovations and Challenges for Social Research. Current Sociology March 2001 49, 2, 29-45.

Kirpal, S. (2011) Labour-Market Flexibility and Individual Careers. Dordrecht: Springer.

Mattingly, C.F. (2007). Acted Narratives. From storytelling to emergent dramas. In D.J. Clandinin (Ed). Handbook of Narrative Inquiry. London: Sage, 405-425.

Stewart, A.J., Ostrove, J.M. and Helson, R. (2001). Middle Aging in Women: Patterns of Personality Change from the 30s to the 50s. Journal of Adult Development, 8, 1, 23-37.

Sugarman, S. (1986) Life-span Development: Theories, Concepts and Interventions. London: Routledge.

Tedder, M., Biesta, G. (2007). Agency and Learning in the Life Course. Towards an ecological perspective. Studies in the Education of Adults, 39, 2, 139-149. 